\title{
The Cairo Conference: Achievements and Canadian Contributions
}

\author{
Michael Shenstone \\ Ottawa, Ontario, Canada
}

\section{Abstract}

The International Conference on Population and Development was a significant achievement in which Canada played a significant role. The challenge remains of finding ways to help bring about the objectives of the conference.

\section{Résumé}

La Conférence Intemationale sur la Population et le Développement représente un accomplissement important dans lequel ie Canada a joué un rôle significatif. Le défit qui demeure est celui de trouver des façons à supporter la réalisation des objectifs de la conférence.

Key Words: population, conference, development

These reflections focus on the achievements of the Cairo International Conference on Population and Development (ICPD) and about the Canadian contribution to it. We also need to consider what Canada, including various interested groups, should do to follow up the conference.

The Conference was an enormous enterprise. It brought together some 11,000 people, including official delegations from 180 countries (many, including Canada's, with NGO representatives among their members), several hundred NGOs, large and small, from all parts of the world and of every possible point of view, and a huge media contingent. It was preceded, over a period of several years, by three large Preparatory Commissions, regional Population Conferences in all parts of the world, and dozens of meetings of specialists.

Before focusing on the conclusions reached by the Conference, I should like to mention an equally or perhaps even more important result, even if an intangible one, of the ICPD. This was the whole vast process itself, which obliged politicians, officials and NGOs in all those countries to familiarize themselves with the issues, work through them, develop thinking on them, and then try to 
meld their positions with those of others. A tremendous work of education consciousness-raising about population and its relationships to other key issues has been accomplished among tens or hundreds of thousands of people around the world. This is a great step forward.

The main tangible result of the ICPD was a 99-page document approved by consensus, with only a few countries expressing reservations about parts of the document; even the Vatican, for the first time, indicated specific approval of important parts of the document, although not all of course. The text is far from being a literary masterpiece; it is, inevitably, expressed in turgid, sometimes ambiguous and often repetitious UN prose. But, as I shall explain in a moment, it enshrines some very important and welcome ideas.

The first thing I would like to point out about the proceedings of the ICPD is that it was not a conference about abortion, despite the impression created by some press reports. Nor was it some kind of battle of the Titans, with the Vatican and its Catholic allies, together with Islamic fundamentalist regimes, ranged against the rest of the world. One thing that may have helped to create this impression was that 90 percent of the text, including some of its most important aspects, had been agreed before Cairo, and so did not get debated there. Some delegates, for instance from Africa, even complained about this, saying that the development aspects to which they attached particular importance got no public attention because there was no argument in Cairo about them. This was true. And the Islamic countries gave ready support to family planning; Iran was especially helpful, and Pakistan took the lead in developing agreement on the contentious "abortion" Paragraph, 8.25. This was finally adopted with only cosmetic amendments, chief among which was to replace the phrase "illegal abortion" with "abortion which is not against the law"l Even the Vatican negotiators were considerably more accommodating during the negotiations than their public spokesmen led one to believe.

\section{So, the Achievements.}

One key point involves the way in which the document emphasizes the multiple interrelationships of all the factors bearing on the situation-underdevelopment, poverty, environmental degradation, low status and lack of education of women, inadequate reproductive and other health facilities including family planning. These interrelationships are stressed in almost every chapter (for example, Paragraphs 3.10 to 3.16 , and 13.1 to 13.3). Just as the problems are interrelated, so the solutions are complementary. The lesson is that the approach to population and development must be fully integrated. 
Another major achievement was that the ICPD got away from the earlier approach of setting government-led demographic goals for the reduction of fertility by so much percent by such-and-such a year. Such goals can too easily turn into coercive (and thus self-defeating as well as morally reprehensible) measures. The talk is no longer of "population control"; the phrase occurs nowhere in the document, I believe. Instead, the conference implicitly recognized that there are a number of developmental and social goals related to population, goals which are highly desirable in themselves, and which, if pursued in a comprehensive way, are at the same time likely to lead to lower fertility in the many areas of the world where it is high, and thus to lead to a slowing of world population growth to a level below the medium level predicted by the United Nations.

These developmental and social goals, set out in various places in the document, include, for example, the empowerment and education of women; reduction of infant and child mortality (because if parents have more confidence that their children will survive, they feel less driven to provide against the contingency of losing several of them); improvement of maternal health and mortality rates, and goals for the provision of comprehensive reproductive health services, including but not limited to family planning.

Indeed, as one Canadian participant at Cairo has said, the big winner at Cairo was women's health, largely because of the importance given to this broad concept of reproductive health, which is repeatedly mentioned throughout the document, and which is defined, along with that of "reproductive rights", in paragraphs 7.2 and 7.3. In other words, population policy is now moving well beyond the provision of contraceptive facilities to those who seek them, even though this rightly remains a core activity. As the document points out, 500,000 women, almost all in the developing world, die each year as a result of various complications of pregnancy, including botched and unsafe abortions. Female genital mutilation also comes in for strong and repeated condemnation.

In a different sphere, the chapter on international migration represents a clear step forward in providing, for the first time, a text with wide international agreement which treats the whole question of migration (including but by no means limited to refugees, as the UNHCR and the Geneva Convention do) in a balanced way from the point of view of developing as well as developed countries. It includes the need to get at root causes, reduce the economic, environmental or political pressure that compel people to move, treat refugees and migrant workers fairly, do more about integration of permanent migrants and their families, and so forth. I personally think it can serve as an internationally agreed blueprint for further action on this increasingly important and controversial international issue. 
Another accomplishment, both in the text and in the process of negotiation, was the large role of NGOs. They influenced the document significantly, particularly during the preparatory process, and also helped to bridge North-South gaps among delegations and among their own organizations. This heightened NGO role started in Rio, but was advanced by Cairo; it places an increased responsibility on NGOs for the future, both in working with and maintaining pressure on their own governments, but also in ensuring follow-up to the ICPD in their own spheres of activity and interest.

But perhaps the biggest accomplishment of Cairo is the assumption implicit throughout the document, and challenged by no-one, that the individual woman, when given the information and the facilities she needs, will normally make sound and enlightened choices about her fertility for herself and her family, to the benefit of society in general. The ability to choose freely is rightly a key theme in the document. I might add that the responsibilities of men are repeatedly mentioned.

What was Canada's contribution to the Conference? As someone who was only an observer and not a member of our official delegation, I can honestly say that we should be proud of what our representatives achieved at Cairo and in the process leading up to the conference. Our delegation played a very skillful and active conciliatory role in several fields, and was in seven out of the eight special informal groups of countries set up to thrash out particularly tough issues.

In the process leading up to Cairo, we were largely responsible for getting agreement on the concept that the quality of family planning and related services is as important as its quantity, so to speak, in securing its acceptability.

Both at Cairo and before the conference, we were among the foremost in promoting agreement by others on the key over-arching concept of reproductive health, which was mentioned earlier. Long hours were spent in little airless conference rooms to bring this about. We also helped to defuse concerns about recommendations in the field of adolescent sexual education.

Canada played a role in negotiating the migration chapter and ensuring that appropriate balance was achieved within it. This was done mainly before rather than at Cairo, so that the chapter survived virtually intact there. We also saw to it that migration issues received mention in other relevant parts of the document because of their importance to population issues generally.

Similarly, we devoted a good deal of effort to ensuring that the concluding chapters dealing with specific goals, cost estimates and follow-up measures were reasonable and logical. 
The problem that remains, and one which worries me greatly, is to ensure that Cairo does not remain just a document and a memory, but is really translated into practical action, both here in Canada and throughout the world. Various individuals and groups need to be involved in this vital task.

At the level of the United Nations, the United Nations Population Commission has been charged with being the agency that oversees the follow-up to the Conference. Canada is playing an important role in this Commission, and the officials at Foreign Affairs are open to input from various individuals and agencies, including the Canadian Population Society. Specific topics are on the agenda for given years, these being reproductive health in 1996 and international migration in 1997.

In Canada, various individuals and groups helped to ensure that population questions were well highlighted in the Government Statement on Canada in the World that followed the Foreign Policy Review. We must continue to pressure CIDA to give greater priority to population questions in its funding decisions.

The Federation of Canadian Demographers is helping to coordinate some of these activities through the formation of a Contact Group on Population and Development. This group should not only be ready to give advice and to apply political pressure, but it should facilitate the involvement of Canadian demographers in population and development activities. It might be suggested that a more appropriate name for the Group would be the "Population and International Development Committee of the FCD". Whatever the exact structure and name, there is plenty of room for people to study the Cairo document, work out the implications that relate to various contexts, and especially become involved in helping to achieve its objectives.

Revised version of papers presented at "Population, Consumption and Sustainable Develpment: A Post-Cairo Serminar" sponsored by The United Church of Canada and The Centre for the Study of Religion in Canada, Toronto, October 1994. 
